\title{
Top-Down or Bottom-Up: Approaches for Addressing Land Degradation in Swaziland and Botswana \\ By Joshua Baller
}

\begin{abstract}
The strategies taken by a particular government are largely based upon their socio-cultural and political background. This paper will examine two countries that, while sharing regional proximity and similar conditions surrounding land degradation, have drastically different forms of governance: Swaziland and Botswana. We will examine the problem of land degradation in these countries generally and what aspects of socio-political organization in each country have affected the rate and severity of the problem. This paper will highlight the policy paths taken by Swaziland and Botswana and examine the irony of their methods. Despite Swaziland's central administration and land tenure systems, they have adopted a more participatory approach to addressing land degradation compared to Botswana, a democratic country.
\end{abstract}

Land degradation is a severe problem facing parts of the developing world. There are many different forms of land degradation, such as soil erosion and desertification. This poses significant challenges for the developing world in particular. Land degradation reduces the amount of arable land that can be used to generate food and cash crops. In addition, it also depletes adequate grazing lands which place strains on livestock handlers. In countries where food security and poverty are issues, land degradation exacerbates the circumstances faced by the socially and economically vulnerable. Finding an effective way to address this problem within economic, political, and social constraints, such as poor economic growth and the structure of state institutions, is a challenge to be faced by governments. This paper examines the specific cases of Swaziland and Botswana. Swaziland is a geographically small, underdeveloped country ruled by an absolute monarchy that is based on a traditional social hierarchy. Botswana is a larger developing country that has had both moderate economic success and success in implementing a stable multi-party democracy. This paper will examine what strategies the governments of Swaziland and Botswana have implemented in order to address the problem of land degradation. Rather than arguing which approach is better, this paper intends to comparatively examine the approaches taken by each respective government and briefly offer explanations as to why they followed a particular approach.

Given the geographical proximity of Swaziland to Botswana, the issues of land degradation faced by the two are fairly similar. Therefore, the geological conditions facing each country are similar, removing the possibility that the approach taken by the two states is determined by geological conditions and allowing us to give more attention to the sociopolitical determinants. This paper will begin by explaining the problem of land degradation in general. Next, we will look at some background information on the two countries in question. Their economies, land tenure systems, and political and social structures will give insight into how they might address the problem. The next section of the paper will look at the policies enacted by Swaziland and Botswana and will examine the difference between them. Despite the autocratic style of governance present in Swaziland, the Swazi government has followed a more participatory approach to dealing with the problem of land degradation (though it will be shown that the system is not fully inclusive). Botswana, though democratic, has opted for a more prescriptive style of policy implementation and development, choosing for the central 
government to have a more prominent role in the shaping of policy. This paper will examine the specifics of this irony and offer an explanation as to why this is so.

Land degradation in general is problematic because of a wide range of possible causes. When dealing with land degradation, one must address both the natural and man-made complications. Land degradation occurs naturally to a certain extent due to fluctuations in weather patterns. Therefore, attempts to address the man-made aspects of the problem through policy must be sensitive to the natural cycles that worsen land degradation. ${ }^{1}$ Policies addressing the man-made problems of land degradation focus primarily on the agricultural sector but must include sensitivities to industry and other economic drivers. A study of soil degradation in Africa since the end of World War Two indicates that the main causes of soil degradation are crop production and overgrazing livestock. ${ }^{2}$ This is particularly problematic for countries with a large agricultural sector and for countries that have chronic problems with drought.

In terms of natural causes for Swazi land degradation, one of the major factors is the climate. Swaziland has a subtropical climate that varies from humid to semi-arid depending on the region in question. ${ }^{3}$ Droughts have been a particular problem and exacerbate the problem of desertification. This is especially true in Swaziland where droughts are part of the natural weather cycle. ${ }^{4}$ This poses significant problems for the agricultural industry. Though agriculture only accounts for $8.6 \%$ of Swaziland's Gross Domestic Product, a large number of Swazi people rely on subsistence farming and $70 \%$ of Swazi people are employed in the agricultural sector. ${ }^{5}$ In addition, many farmers also raise cattle and other livestock. ${ }^{6}$ The formation of cattle tracks on communal rangeland in Swaziland has led to soil erosion and the formation of gullies. ${ }^{7}$ The large reliance on arable land and grazing land means that the degradation of soil can cause significant problems for Swaziland's food supply and limits growth potential in these economic sectors. Going back to the 1980s, data shows a general decline in agricultural output and an increase in grazing pressure in Africa. ${ }^{8}$ With less land upon which to raise livestock and grow crops, it is likely that cycles of poverty and malnourishment will continue. However, the current land tenure system and the reasons behind why so many farmers raise livestock are difficult to change through policy.

Land tenure and property ownership in Swaziland can be viewed as being relatively tied to traditional forms of ownership. As an absolute monarch, King Mswati III owns and controls $72 \%$ of the land (called "Swazi Nation Land") which is divided into 180 chiefdoms." Land in these chiefdoms is allocated to the heads of households (married men) in varying proportion based on lineage, age, need, and social status. ${ }^{10}$ This is done for the purpose of

\footnotetext{
${ }^{1}$ Lindsay C. Stringer, Chasca Twyman, and David S. G. Thomas, "From Global Politics to Local Land

${ }^{2}$ Charles Parrings and Jon Lovett, "Policies for Biodiversity Conservation: The Case of Sub-Saharan Africa," International Affairs (Royal Institute of International Affairs 1944-) 75, No. 2 (1999): 285.

${ }^{3}$ Christina Healy, "Swaziland," Our World: Swaziland (August 2011): 1, Canadian Points of View Reference Centre, EBSCOhost (accessed October 18, 2011).

${ }^{4}$ Healy, "Swaziland," EBSCOhost.

${ }^{5}$ Ibid.

${ }^{6}$ Ibid.

${ }^{7}$ Lindsay C. Stringer, Chasca Twyman, and David S. G. Thomas, "Combating Land Degradation through Participatory Means: The Case of Swaziland," Ambio 36, No. 5 (2007): 388.

${ }^{8}$ Parrings and Lovett, "Policies for Biodiversity Conservation," 285-286.

${ }^{9}$ Lindsay C. Stringer, Chasca Twyman, and David S. G. Thomas, 158.

${ }^{10}$ Stringer, "Testing the Orthodoxies," 158.
} 
directing agricultural activities. ${ }^{11}$ The remaining Swazi Nation Land is considered communal grazing land for cattle and other purposes. ${ }^{12}$ This system of land ownership is heavily based on tradition and patronage. How resources have been distributed and used under this system has resulted in varying degrees of land degradation across the country. ${ }^{13}$ However, it would be virtually impossible to use policy to reform these institutions. Tradition also forms the basis for government and power structures on the national and local levels. ${ }^{14}$ Therefore, policy aimed at combating land degradation caused by these patterns of resource use would involve a reformation of the system to reflect more democratic values in terms of land allocation. In addition, the historical legacy of this form of social organization would be difficult to uproot in a society where democracy has no real legacy. Regarding the problem of overgrazing, the issue is the amount of cattle grazing on communal lands. In traditional Swazi culture, the ownership of cattle is a symbol of power and social prestige. ${ }^{15}$ Therefore, it is considered necessary for a man to attain as many cows as he can. This increases the amount of pressure on the already strained communal rangelands. There was also a minor issue on privately-owned lands, especially during the colonial era. Many "squatters" were occupying portions of private land and thus many land-owners pressured the government to evict them. ${ }^{16}$ One of the arguments given by private-landowners was that the squatters, in raising their cattle on the private lands, were spreading the problem of soil erosion. ${ }^{17}$ Though Swaziland has achieved independence, the government still battles with the issue of squatters on private land and the environmental impacts that these squatters have on privately-owned farms as well as on Swazi Nation Land. This is because these issues, formerly faced by the colonial power, now must be addressed by Swaziland's traditional governance systems. The high level of influence that tradition has on Swazi government and society could indicate a preference for centralized solutions for the issue. The government is an absolute monarchy and society traditionally places much of the power in the hands of elders and other specific individuals, meaning that, in the case of solving land degradation, it is possible that the government could favour a more top-down approach. However, the social hierarchies of the traditional system may also necessitate community involvement as community members with higher social prestige may be included in the decision-making process. We will now take a quick look at Botswana's background relating to land degradation.

$84 \%$ of Botswana is covered by the Kalahari Desert and the climate is considered semiarid. ${ }^{18}$ Like in Swaziland, droughts are a frequent problem though Botswana also suffers from sandstorms and dust storms. ${ }^{19}$ Dust storms are hazardous for agriculture as they displace needed top-soil, removing essential nutrients and soil to anchor the roots in. A major difference between Botswana and Swaziland is that Botswana is not as heavily reliant on agriculture. Less than one percent of Botswana is considered arable and thus the majority of farming that exists

\footnotetext{
11 Ibid.

12 Ibid.

${ }^{13}$ Stringer, Twyman, and Thomas, "Combating Land Degradation," 388.

14 Ibid.

15 Ibid.

${ }^{16}$ Hamilton Sipho Simelane, "The State, Landlords, and the Squatter Problem in Post-Colonial Swaziland," Canadian Journal of African Studies 36, No. 2 (2002): 331-332.

${ }^{17}$ Simelane, "The State," 334.

${ }^{18}$ Ellen Bailey, "Botswana," Our World: Botswana (August 2011): 1, Canadian Points of View Reference Centre, EBSCOhost (accessed October 18, 2011).

${ }^{19}$ Bailey, "Botswana," EBSCOhost.
} 
is on the subsistence level. ${ }^{20}$ Though it is not a significant contributor to economic performance, this subsistence agriculture provides food for the rural communities that rely on them and thus land degradation poses a significant problem. More importance is given to livestock than to agricultural production. In areas such as the Matsheng, the local economy relies on the livestock industry. ${ }^{21}$ A downside to this is that, as it is in Swaziland, overgrazing is helping cause land degradation in the form of desertification. Large amounts of cattle on little fertile land have placed significant stress on the environment. Botswana has, however, altered its system of land allocation so that the problems created by the traditional system of land distribution used in Swaziland are not as evident. Moreover, the more democratic nature of Botswana creates a different policy environment.

Land allocation in Botswana was traditionally the power of local chiefs who would distribute communal land to cattle herders. ${ }^{22}$ However, this power was taken away in 1968 when the government passed the Tribal Land Act, establishing Tribal Land Boards which attempted to avoid the "arbitrary" land allocations. ${ }^{23}$ This policy will be discussed in greater detail later. In addition, certain democratic practices had existed in Botswana prior to colonization. Communities were governed by chiefs that shared power with village councils. ${ }^{24}$ The councils not only voiced public opinion on issue but also served as advisory committees to the chiefs on sustainable land and water allocation. ${ }^{25}$ Today, Botswana is a stable multi-party democracy with a strong central government. Therefore, there is a greater amount of public participation in governing the country. Unlike in Swaziland, there is already a tradition of participation by everyone. This means that, combined with the traditional legacy of public participation in ecological conservation, it would be more likely that a participatory strategy to fight an issue, such as land degradation, would be more successful and more efficient. Unfortunately, as we will see, the government of Botswana has not capitalized on this, choosing instead to implement a more prescriptive style of policy development and implementation. One negative aspect of this system is that subsidies and resource grants to the cattle industry are done on the basis of patronage as is the case in Swaziland. ${ }^{26}$ With this background, we can now look into the different policy measures that the governments of Swaziland and Botswana have employed to fight land degradation.

Swaziland, as of 1996, is a signatory of the United Nations Convention to Combat Desertification (UNCCD). As such, it is committed to actively fighting land degradation within its borders. The UNCCD does not prescribe a general plan to address the problem. Rather, it places responsibility for action in the hands of developing countries through the creation of National Action Programs. ${ }^{27}$ According to the UNCCD, these action programs were to be constantly updated through a "participatory process on the basis of lessons from field action, as

\footnotetext{
${ }^{20}$ Bailey, "Botswana," EBSCOhost.

${ }^{21}$ R. F. Rohde et al, "Dynamics of Grazing Policy and Practice : Environmental and Social Impacts in Three Communal Areas in Southern Africa," Environmental Science and Policy 9 (2006): 305.

${ }^{22}$ J. Clover and S. Eriksen, "The Effects of Land Tenure Change on Sustainability: Human Security and

Environmental Change in Southern African Savannas," Environmental Science and Policy 12 (2009): 59.

${ }^{23}$ Rohde et al, "Dynamics of Grazing Policy,” 305.

${ }^{24}$ Rodger Yeager, "Democratic Pluralism and Ecological Crisis in Botswana," The Journal of Developing Areas 23, No. 3 (1989): 388.

${ }^{25}$ Ibid..,388.

${ }^{26}$ Ibid., 385.

${ }^{27}$ Ragnar Oygard, Trond Vedeld, and Jens Aune, Good Practices in Drylands Management (USA: The World Bank, 1999), 20.
} 
well as the results of research." 28 Swaziland has built its own National Action Program on the basis of community participation. First, the government sensitized the people to the problem of land degradation through radio broadcasts and awareness-raising initiatives. ${ }^{29}$ Local level workshops began consulting with community leaders, chiefs, village elders, government officials, and NGOs. ${ }^{30}$ However, these consultations were facilitated through traditional institutions and were not frequently attended by poor farmers. ${ }^{31}$ In September 1997, the First National Forum was held which prioritized focus areas for policy and eventually led to the passing of the National Action Program in 2000. ${ }^{32}$

The Program focuses on setting up institutional arrangements for addressing desertification but, they only focus on "government and elite" institutions and ignore local level institutions. ${ }^{33}$ In terms of targeting specific sectors, the NAP has a narrow focus. The policy is mainly concerned with combating land degradation caused by and affecting communal grazing lands because it will "enhance opportunities for community participation.",34 In the specific case of Engcayini, rangelands were fenced to control grazing, feedlots were constructed, and re-vegetation programs were started around one of the larger gullies. ${ }^{35}$ Land degradation caused by overgrazing and livestock are more visible than are other forms of degradation (such as nutrient depletion) and thus, as in past policies, are the focus of the NAP. ${ }^{36}$ Therefore, there is significantly less concern given to land degradation that is caused by and affects agricultural activities on farmland. As previously mentioned, social status played an important role on the consultation process. This was reflected in the target areas for the policy given that, as mentioned, cattle ownership indicated high social standing. In addition, one of the main orthodoxies behind the NAP was that it was the poor farmers who were the main causes of the problem. ${ }^{37}$ This is not true given that it is generally the wealthier members of rural Swaziland that own cattle and use communal grazing land. ${ }^{38}$ As demonstrated, though the government attempted to address the problem of land degradation through a comprehensive, participatory strategy, the policy was formed mainly through the traditional social hierarchy that largely ignores the problems of the poorer farmers. This is in contrast to Botswana's more comprehensive strategy to deal with land degradation that moves away from traditional forms of hierarchy.

The government of Botswana has a far more exhaustive definition of what constitutes land degradation. Unlike in Swaziland where only visible signs of degradation are given significant attention, Botswana's government examines both visible soil characteristics and other indicators such as decreases in perennial grasses and changes in soil structure. ${ }^{39}$ Despite this broader definition, the policies enacted tend to address the visible signs of land degradation. As previously mentioned, Botswana had taken action on the problem of land

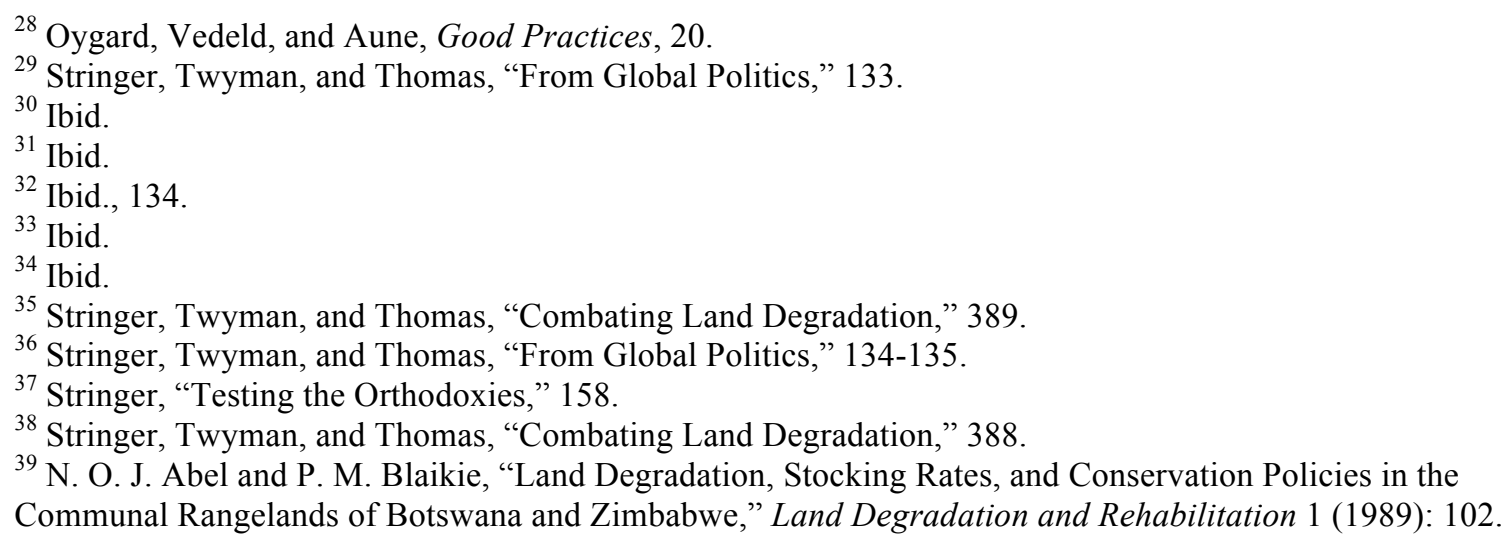


degradation beginning in 1968. This began with the Tribal Land Act which altered the means by which communal land was allocated. The next action was the Tribal Grazing Lands Policy. Implemented in 1979, the TGLP sought to improve rangeland conditions by introducing rotational grazing, controlled breeding, extensive fencing, private land ownership, the removal of large livestock owners and herds from overgrazed communal areas, and by reserving lands for future use. ${ }^{40}$ After limited success from the TGLP, the government introduced the National Policy on Agriculture Development in $1991 .^{41}$ This was not a drastic new strategy. Rather, it built on the TGLP through subsidies and further fencing of communal grazing lands. ${ }^{42}$ These policies indicate a tendency for top-down policy prescriptions for different regions by the central government. However, the central government is not completely deaf to the needs and desires of the poor rural areas. Concerns are expressed through elections and lobby groups while the government gives out rewards to regions and groups that support them. ${ }^{43}$ There is, however, limited participation in how current land degradation is addressed.

In the Molopo of Botswana, farmers participated in research and consultations on land degradation. ${ }^{44}$ Local farmers participated in a series of environmental and social research sessions where information was collected on the social and environmental situations facing the community. ${ }^{45}$ The locals were able to take the information gathered through research to community workshops and policy discussion workshops where local conditions and concerns were shared with other farmers as well as policy institutions, international organizations, and local collaborators. ${ }^{46}$ These did not yield policies on the national level. However, many local initiatives were established such as the rotation of subsistence crops to increase yields and restore soil nutrients. ${ }^{47}$ This presents an interesting case. Botswana has a history of citizen participation at both the local and national level; however, the only level at which community participation was given any serious consideration was the local level. Swaziland, on the other hand, structured their response to land degradation such that the community was able to participate in some fashion in determining a national direction. One possible way to account for this ironic difference is that in making the shift towards a state modeled on Western democracy, the government adopted the more centralized approach to resolving issues that are sometimes pursued in Western democracies elsewhere. Strategies for addressing national challenges tend to be formulated at the executive level of government primarily through consultation with experts and various stakeholders. Therefore, it is unlikely that there would be meaningful consultation with farmers. Furthermore, as mentioned previously, Botswana's distribution of subsidies is based on patronage. What this could mean is that the regions most affected most by land degradation are not "favoured" by the government and they therefore do not receive as much attention. Swaziland's emphasis on traditional social structures necessitates the participation of at least some members of the community, meaning that participatory action should not be as surprising as some may think. Moreover, the structure of

\footnotetext{
${ }^{40}$ Rohde et al, "Dynamics of Grazing Policy," 305.

${ }^{41}$ Ibid., 306.

${ }^{42}$ Ibid., 306.

${ }^{43}$ Yeager, "Democratic Pluralism," 389-390.

${ }^{44}$ Andrew J. Dougill et al, "Soil Degradation Assessment in Mixed Farming Systems of Southern Africa: Use of Nutrient Balance Studies for Participatory Degradation Monitoring," The Geographical Journal 168, No. 3 (2002): 198.

${ }^{45}$ Dougill et al, "Soil Degradation," 199.

${ }^{46}$ Ibid., 199 .

${ }^{47}$ Ibid., 205.
} 
traditional Swazi society gives those members of the community access to the national decision-making institutions which gives communities some say in the direction of national policy.

The two cases studies above present an interesting irony. Swaziland is an absolute monarchy with no legacy of democratic institutions. Botswana has developed into one of Africa's few stable and peaceful multi-party democracies. Nevertheless, the government of Swaziland has pursued a more inclusive and participatory strategy to combat land degradation than Botswana. Having said that, the Swazi government's idea of inclusion is based on traditional forms of social organization and hierarchy, effectively excluding the lower classes of rural Swazi society. Therefore, despite higher levels of consultation than in Botswana, the process in Swaziland tends to produce solutions geared towards the interests of the elites. The government of Botswana, favouring a more centralized form of democratic government, has opted for government-initiated policies with minimal consultation from farmers. Despite the obvious forms of expression such as elections and lobby groups, direct participation in policy formulation has not been common. Due to the fact that Botswana is plagued by the problem of patronage, once again national strategies are developed for the regions that are favoured by government. This yields one similarity with the Swaziland approach: the strategy produces solutions that address the concerns of an elite group of society though Botswana's elites are not determined by tradition. These differing strategies in tackling land degradation do not reflect the similarities in terms of natural and man-made conditions affecting land degradation. Rather, they reflect the socio-political structures and cultural backgrounds of each country. 


\section{Bibliography:}

Abel, N. O. J., and Blaikie, P. M. "Land Degradation, Stocking Rates and Conservation Policies in the Communal Rangelands of Botswana and Zimbabwe." Land Degradation and Rehabilitation 1 (1989): 101-123.

Bailey, Ellen. "Botswana." Our World: Botswana (August 2011): 1. Canadian Points of View Reference Centre, EBSCOhost (accessed October 18, 2011).

Clover, J., and Eriksen, S. "The Effects of Land Tenure Change on Sustainability: Human Security and Environmental Change in Southern African Savannas." Environmental Science and Policy 12 (2009): 53-70.

Dougill, Andrew J., Twyman, Chasca, Thomas, David S. G., and Sporton, Deborah. "Soil Degradation Assessment in Mixed Farming Systems of Southern Africa: Use of Nutrient Balance Studies for Participatory Degradation Monitoring." The Geographical Journal 168, No. 3 (2002): 195-210.

Healy, Christina. "Swaziland." Our World: Swaziland (August 2011): 1. Canadian Points of View Reference Centre, EBSCOhost (accessed October 18, 2011).

Oygard, Ragnar, Vedeld, Trond, and Aune, Jens. Good Practices in Drylands Management. USA: The World Bank, 1999.

Parrings, Charles, and Lovett, Jon. "Policies for Biodiversity Conservation: The Case of SubSaharan Africa." International Affairs (Royal Institute of International Affairs 1944-) 75, No. 2 (1999): 281-305.

Rohde, R. F., Moleele, N. M., Mphale, M., Allsopp, N., Chanda, R., Hoffman, M. T., Magole, L., and Young, E. "Dynamics of Grazing Policy and Practice: Environmental and Social Impacts in Three Communal Areas of Southern Africa." Environmental Science and Policy 9 (2006): 302-316.

Simelane, Hamilton Sipho. "The State, Landlords, and the Squatter Problem in Post-Colonial Swaziland." Canadian Journal of African Studies 36, No. 2 (2002): 329-354.

Stringer, Lindsay C. "Testing the Orthodoxies of Land Degradation Policy in Swaziland." Land Use Policy 26 (2009): 157-168.

Stringer, Lindsay C., Twyman, Chasca, and Thomas, David S. G. "Combating Land Degradation through Participatory Means: The Case of Swaziland." Ambio 36, No. 5 (2007): 387-393. 
Stringer, Lindsay C., Twyman, Chasca, and Thomas, David S. G. "From Global Politics to Local Land Users: Applying the United Nations Covenant to Combat Desertification in Swaziland." The Geographical Journal 173, No. 2 (2007): 129-142.

Twyman, Chasca. "Participatory Conservation? Community-Based Natural Resource Management in Botswana." The Geographical Journal 166, No. 4 (2000): 323-335.

Yeager, Rodger. "Democratic Pluralism and Ecological Crisis in Botswana." The Journal of Developing Areas 23, No. 3 (1989): 385-404. 